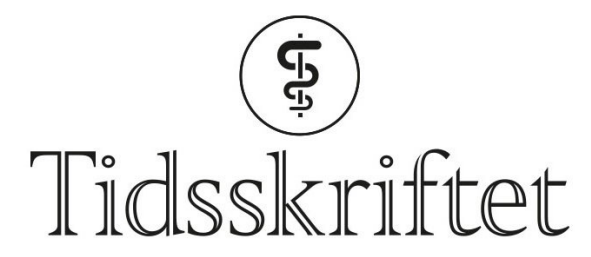

DEN NORSKE LEGEFORENING

\title{
Illebefinnende på godt og vondt
}

SPRÅKSPALTEN

EIRIK MADSEN

E-post: eirik.madsen@helse-forde.no

Eirik Madsen (f. 1987) er lege i spesialisering ved Førde sentralsjukehus.

Dersom noen har fått et illebefinnende, kan det være grunn til å spørre seg hva vedkommende egentlig fikk.

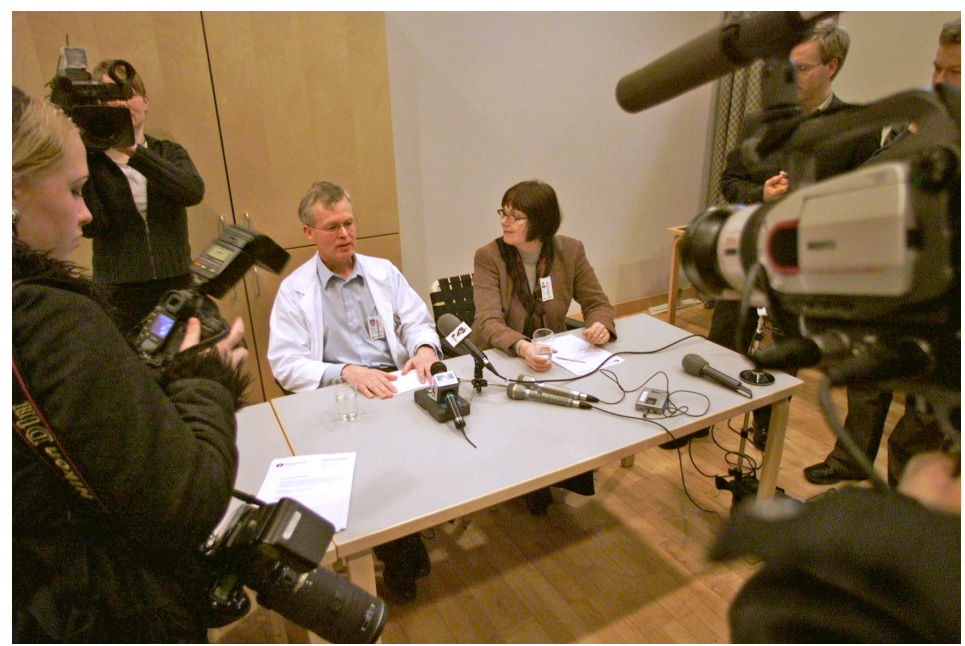

Oslo 16.1.2002: Overlege Otto A. Smiseth, avdelingsleder ved Hjertemedisinsk avdeling, Oslo universitetssykehus, Rikshospitalet, og sykehusets informasjonssjef Trine Lind meddelte på en pressekonferanse at Thorbjørn Jagland ville bli varende på Rikshospitalet $i$ noen dager etter et illebefinnende. Foto: Ørn E. Borgen/NTB scanpix

«Illebefinnende» er et allmennspråklig begrep som betegner et plutselig anfall av ubehag eller sykdom (1). Ordet kan i bred forstand brukes om enhver tilstand eller hendelse som medfører det motsatte av velbefinnende, men brukes ofte om akuttmedisinske tilstander som hjerneslag, angina pectoris og epileptiske anfall. Begrepet er uspesifikt og bør derfor anvendes med varsomhet i medisinsk litteratur og i pasientjournaler.

Ordet ble dannet i Danmark på begynnelsen av 180o-tallet (2) som en sammensetning av «ilde», fra norrønt illr = ond, og befinden = tilstand, som er et importord fra tysk.

Ildebefindende har beholdt sin opprinnelige form på dansk, men på norsk er skrivemåten gradvis endret til illebefinnende. Bruken ser ut til å ha forandret seg lite de siste par hundre år.

Søk på «illebefinnende» i det digitale nasjonalbiblioteket (bokhylla.no) gir mer enn 5000 treff(3). I dagspressen brukes illebefinnende gjerne i tilfeller der sykdomsbildet eller dødsårsaken er ukjent og/eller taushetsbelagt. I forskriftstekster brukes illebefinnende, 
sannsynligvis bevisst, for å romme et stort spekter av «juridiske» tilstander der årsaken til ubehaget er irrelevant. Skillet mellom illebefinnende, sykdom, svakhet, skade, lidelse, plage og lyte er og forblir uklart.

I Tidsskriftets nettutgave, som omfatter årgangene etter 20oo, gir illebefinnende 12 treff (4). I vitenskapelige artikler brukes illebefinnende hovedsakelig om selvrapporterte pasientopplevelser, men i én artikkel nevnes kvalme og illebefinnende som symptomer på hurtig innsettende hyponatremi (5). Dette impliserer et kunstig skille mellom kvalme og andre former for illebefinnende, og dermed blir det ytterligere uklart hva begrepet egentlig rommer.

I tidsskrifter og aviser brukes ordet illebefinnende ofte i minneord, sannsynligvis fordi det her er tilstrekkelig å formidle at noen er avgått ved døden, fremfor å omtale hvordan eller hvorfor vedkommende døde. Illebefinnende kan på denne måten brukes eufemistisk, samtidig som ordet ivaretar personvern og integritet.

Illebefinnende er altså et uspesifikt allmennspråklig begrep som kan betegne mange ulike former for plutselig innsettende ubehag eller sykdom. Ordet kan i visse sammenhenger være nyttig, nettopp fordi det er uspesifikt. Som helsepersonell bør man imidlertid være varsom med å bruke det som en medisinsk fagterm i de tilfeller man kjenner illebefinnendets årsak eller symptombilde.

\section{LITTERATUR:}

1. Illebefinnende. I: Bokmålsordboka. http://ordbok.uib.no/perl/ordbok.cgi?OPP-

illebefinnende (7.7.2017).

2. Ildebefindende. I: Ordbog over det danske Sprog. http://ordnet.dk/ods/ordbog?query-

ildebefindende (10.7.2017).

3. Illebefinnende. I: Nasjonalbiblioteket. www.nb.no/nbsok/search?page $=0 \&$ menuOpenfalse\&instanttrue\&actionsearch\&currentHit=o\&currentSesamid=\&deweyClass=\&deweyLevel=o\&deweyMenuOpenfalse\&searchStringillebefinnende (7.7.2017).

4. Illebefinnende. I: Tidsskrift for Den norske legeforening. http://tidsskriftet.no/sok?search_api_views_fulltextillebefinnende\&search_api_views_fulltext_1= (7.7.2017).

5. Aakre KM, Hov GG, Skadberg $\emptyset$ et al. Varsling av sterkt avvikende analyseresultater til rekvirenter utenfor sykehus. Tidsskr Nor Legeforen 2013. doi:10.4045/tidsskr.13.0709 [CrossRef]

Publisert:30. oktober 2017. Tidsskr Nor Legeforen. DOI: 10.4045/tidsskr.17.0354

(C) Tidsskrift for Den norske legeforening 2020. Lastet ned fra tidsskriftet.no 